\title{
INVENTARISASI POTENSI SUMBER DAYA EKOWISATA DI DANAU WAY JEPARA LAMPUNG TIMUR
}

\author{
(Inventory Potential Ecotourism Resource in the Lake Way Jepara, East Lampung)
}

\author{
Imam Nur Muchlas, Agus Setiawan, Gunardi Djoko Winarno, Sugeng P. Harianto
}

Jurusan Kehutanan, Universitas Lampung.

JI. Prof. Dr. Sumantri Brojonegoro No. 1, Rajabasa, Bandar Lampung.

E-mail, Imamnur0202@gmail.com

\begin{abstract}
Lake Way Jepara is one of the tourist destinations in East Lampung district that has the potential to be developed. An inventory of potential resources of ecotourism at Lake Way Jepara is done by the method of survey to analyze and document the ecotourism resources at the site. The result of this research shows that the potential of ecotourism resources reside on the Mainland and in the waters of the Lake, including: the potential of the landscape, flora and fauna, amenities and services, accommodation and infrastructure. The Mainland covers landscape view of the street, hallway view arboretum, view of the dam and the beauty of the landscape of the Lake. Resources of flora and fauna includes 29 species of trees, 26 wildlife species and 21 species of fish. The available infrastructure includes the main road, the alternative way, path tracking, bridges, parking and irrigation canals. Facilities and services include an Advisory Board, a gazebo, a symbolic monument, the Hall opens and seating. Accommodation available: hotel, camping ground, operational as well as home stay. The spread of ecotourism resources clumped in two zones, so that will make it easier in the planning and development of ecotourism.
\end{abstract}

Key words: Lake Way Jepara, inventory of the resources of ecotourism.

\begin{abstract}
Abstrak
Danau Way Jepara merupakan salah satu destinasi wisata di Kabupaten Lampung Timur yang memiliki potensi untuk dikembangkan. Inventarisasi potensi sumber daya ekowisata di Danau Way Jepara dilakukan dengan metode survei untuk menganalisis dan mendokumentasikan sumber daya ekowisata di lokasi. Hasil dari penelitian ini menunjukkan bahwa potensi sumber daya ekowisata terdapat di daratan dan di perairan danau, yaitu: potensi lanskap, flora dan fauna, fasilitas dan pelayanan, akomodasi serta infrastruktur. Lanskap daratan meliputi view lorong jalan, view arboretum, view bendungan dan keindahan lanskap danau. Sumber daya flora dan fauna meliputi 29 spesies pohon, 26 spesies satwa dan 21 spesies ikan. Infrastruktur yang tersedia meliputi jalan utama, jalan alternatif, jalan tracking, jembatan, parkir dan saluran irigasi. Fasilitas dan pelayanan yang tersedia di antaranya papan himbauan, gazebo, tugu simbolis, aula terbuka dan tempat duduk. Akomodasi yang tersedia yaitu: hotel, camping ground, vila operasional serta home stay. Persebaran sumber daya ekowisata mengelompok pada dua zona, sehingga akan memudahkan dalam perencanaan dan pengembangan ekowisata.
\end{abstract}

Kata kunci: Danau Way Jepara, Inventarisasi sumber daya ekowisata. 


\section{Pendahuluan}

Danau Way Jepara adalah salah satu destinasi wisata di Lampung Timur. Danau ini merupakan danau alam yang terbentuk akibat aktivitas gunung api. Danau ini dibangun dan dimanfaatkan untuk irigasi pertanian (Dinas PU Lampung Timur, 2016). Menurut penjelasan masyarakat setempat pembangunannya dimulai sekitar tahun 1970. Saat ini kondisi alam di lokasi terlihat masih baik dan belum terlihat tanda-tanda pencemaran lingkungan, namun intensitas kunjungan wisatawan mengalami penurunan yang signifikan. Jika dilihat sekilas, potensi sumber daya ekowisata belum dimanfaatkan dengan baik. Hal tersebut menjadi peluang untuk dikembangkan untuk kegiatan ekowisata. Inventarisasi sumber daya ekowisata dibutuhkan sebagai langkah awal untuk membangkitkan potensi yang ada di Danau Way Jepara, hal tersebut erat kaitannya dalam menentukan perencanaan dan strategi dalam pengembangan ekowisata di masa depan.

Untuk membangkitkan kegiatan ekowisata di Danau Jepara dinilai perlu adanya peran masyarakat lokal dan stakeholder terkait. Pola ekowisata berbasis masyarakat diharapkan sesuai dengan kondisi masyarakat desa. Menurut Hijriati dan Mardiana (2014), ekowisata berbasis masyarakat dinilai cocok, hal tersebut karena ekowisata berbasis masyarakat mengakui hak masyarakat lokal dalam mengelola kegiatan wisata di kawasan yang mereka miliki secara adat ataupun sebagai pengelola. Menurut Winasis (2016), komponen-komponen yang terdapat dalam masyarakat memiliki fungsi sebagai item produk kepariwisataan dan menjadi rangkaian aktivitas wisata yang terpadu, sehingga menjadi karakteristik yang unik, sesuai dengan kondisi masyarakat, geografis serta sosial budaya setempat

Tujuan penelitian ini adalah untuk menganalisis dan mendokumentasikan sumber daya ekowisata yang meliputi potensi flora dan fauna, lanskap dan view, infrastruktur, akomodasi, serta fasilitas dan pelayanan yang terdapat di Danau Way Jepara.

\section{Metode}

\section{Lokasi Objek dan Waktu Penelitian}

Berdasarkan letak administratif lokasi objek penelitian ini berada di Desa Labuhan Ratu Danau, Kecamatan Way Jepara, Kabupaten Lampung Timur, Provinsi Lampung. Pengambilan data dilakukan pada bulan Januari-Februari 2018. Peta lokasi penelitian dapat dilihat pada Gambar 1.

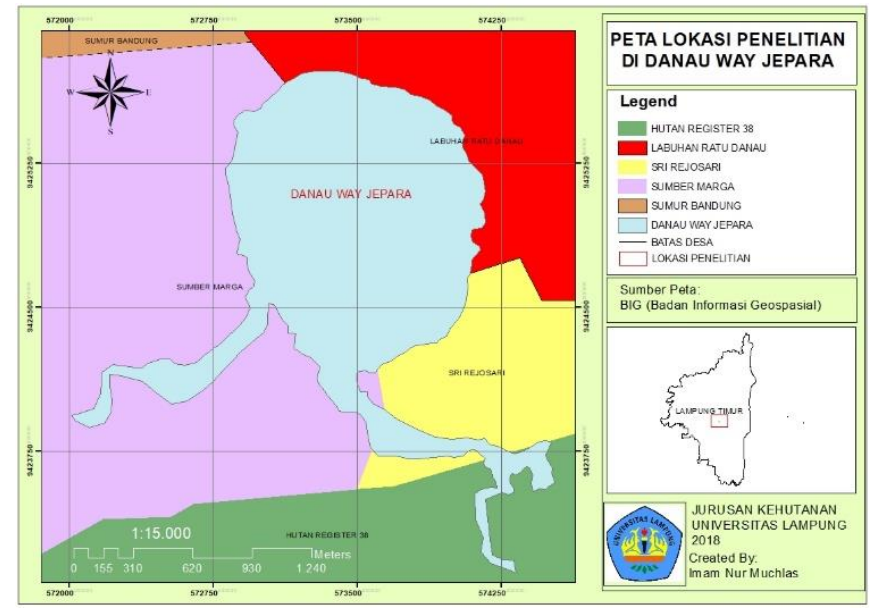

Gambar 1. Peta lokasi penelitian di Danau Way Jepara.

Figure 1. Location map of Lake Research Way Jepara. 


\section{Jenis Data, Pengumpulan data dan Analisis Data}

Inventarisasi potensi sumber daya ekowisata dilakukan dengan mengumpulkan data primer dan data sekunder. Data primer dikumpulkan dengan metode survei langsung di lokasi. Data primer yang diperlukan berupa foto objek sumber daya ekowisata, dikumpulkan dengan tally sheet dan didokumentasikan menggunakan kamera, kemudian dideskripsikan sesuai keadaan di lokasi. Data titik-titik koordinat sumber daya ekowisata ditentukan dengan GPS (Global Positioning System) dan diolah dengan aplikasi Arc Gis 10.5 untuk mengetahui dan menghasilkan peta persebaran sumber daya ekowisata, peta tersebut akan dianalisis sebagai pendukung rencana pengembangan sumber daya ekowisata.

Data dan informasi sekunder dari lokasi maupun dari literatur dikumpulkan dengan mengutip literatur yang relevan, kemudian akan dianalisis secara deskriptif sebagai bahan alternatif pengembangan. Saran pengembangan dilakukan dengan membandingkan pengelolaan sumber daya ekowisata serupa di daerah lain yang dianggap telah baik.

\section{Hasil Dan Pembahasan}

\section{Sejarah Pengelolaan wisata di Danau Way Jepara}

Sejarah terbentuknya kubah danau diyakini dari hasil aktivitas gunung berapi. Struktur lapisan batuan dan dinding danau terdiri dari batuan basalt dan tuffa dengan berbagai macam ciri fisik. Kedalaman Danau Way Jepara kurang lebih $26 \mathrm{~m}$ dengan diameter berkisar $1,9 \mathrm{~km}$. Semula luasannya hanya seluas $5 \mathrm{ha}$, pada tahun 1972 diperluas menjadi sekitar 200 ha. Air Danau Way Jepara berasal dari tiga hulu sungai, yaitu: sungai Way Habar, Way Jejawai dan Way Jepara serta berhulu di DAS Register 38 Gunung Balak (Dinas PU Lampung Timur, 2016).

Latar belakang sejarah wisata di dimulai setelah pembangunan proyek irigasi diselesaikan, mulai saat itu banyak masyarakat yang berlibur atau sekedar untuk menikmati pemandangan Danau Way Jepara. Berdasarkan penjelasan informan kunci yang bernama Bapak Khumaydi dan Bapak H. Mu'alim yang sejak tahun 1970 sudah tinggal di Danau Way Jepara, bahwa dahulu pengunjung belum mengenal Taman Nasional Way Kambas dan hanya mengenal Danau Way Jepara. Hal tersebut membuat intensitas kunjungan wisata ke Danau Way Jepara tinggi. Saat itu pengelola sering mengundang beberapa artis ibu kota untuk meramaikan acara, terutama pada hari libur nasional atau hari peringatan keagamaan, Idul Fitri dan menyambut tahun baru.

\section{Karakteristik Sosial dan Budaya Masyarakat}

Desa Labuhan Ratu Danau memiliki luas sekitar $7,7 \mathrm{~km}^{2}$ yang terdiri dari 4 dusun dan terbagi menjadi 13 RT. Jumlah penduduknya pada tahun 2010 berjumlah 1.297 orang dengan perbandingan 673 orang laki-laki dan 624 orang perempuan. Agama mayoritas adalah Islam dengan jumlah penganut 1.356 orang dan sebagian kecil beragama Katolik sebanyak 20 orang (BPS Lampung Timur, 2017). Mayoritas penduduk bekerja sebagai petani, pekerjaan lainnya yaitu nelayan, wiraswasta dan pegawai negeri sipil. Sebagian besar masyarakat adalah masyarakat menengah ke bawah, dengan kondisi SDM belum paham teknologi.

Aktivitas sosial budaya masyarakat yang telah di inventarisasi yaitu aktivitas keagamaan dengan perpaduan kultur Jawa. Hal tersebut dikarenakan adat istiadat tersebut dipercaya turun temurun. Sedangkan hanya sebagian kecil yang bersuku Lampung asli. Berdasarkan data aktivitas sosial dan budaya pada Tabel 1, dapat diketahui aktivitas yang menarik dan dapat menjadi item wisata sosial budaya, yaitu Malam 1 Assuro, dan gotong royong, hal ini dikarenakan kegiatan tersebut melibatkan 
masyarakat ramai dan dapat dijadwalkan secara tetap. Aktivitas sosial dan budaya yang dilakukan masyarakat seperti pada Tabel 1.

Selama ini belum ada kelompok masyarakat atau pemuda di sekitar Danau Way Jepara yang bergerak dalam pengelolaan wisata (Pokdarwis). Untuk menunjang ekowisata, maka haruslah tersedia kelembagaan yang kuat. Menurut Hilman (2017), cara pelembagaan kepariwisataan desa harus mempunyai sebuah kebijakan yang baik, dilakukan secara bersinergi antar lembaga dengan masyarakat melalui para steakeholder yang terlibat, guna menemukan kemitraan dan juga pola organisasi pemerintahan yang relevan dengan kondisi desa. Kesadaran akan potensi sumber daya ekowisata masih belum tumbuh. Menurut penelitian Priyono, (2012) yang dilakukan di Taman Wisata Alam Bukit Tangkiling, bahwa dalam pengembangan wisata berbasis masyarakat yang perlu mendapat perhatian dalam pengembangan pariwisata adalah peningkatan kualitas sumber daya manusia dan keterampilan masyarakat lokal di sekitar kawasan wisata. Berdasarkan karakteristik sosial dan budaya maka pengembangan kegiatan ekowisata harus tetap memperhatikan norma-norma agama Islam, ditinjau dari segi pekerjaan yaitu petani maka atraksi ekowisata juga dapat juga diarahkan untuk agro-ekowisata.

Tabel 1. Aktivitas sosial budaya masyarakat.

Table 1. Activities of social and cultural.

\begin{tabular}{clll}
\hline No & Aktivitas sosial budaya & Rangkaian Waktu Pelaksanaan & Lokasi pelaksanaan \\
\hline 1 & Tiba'al berjanji/berjanjian & $\begin{array}{l}\text { Upacara kelahiran, upacara } \\
\text { kematian, syukuran pernikahan. }\end{array}$ & Rumah pemilik hajat \\
\hline 2 & Yasinan & $\begin{array}{l}\text { Malam Jumat atau saat upacara } \\
\text { kematian }\end{array}$ & Rumah warga atau masjid \\
\hline 3 & Sewelasan & $\begin{array}{l}\text { Malam tanggal 11 Maulud } \\
\text { (kalender Jawa) }\end{array}$ & Rumah warga atau masjid \\
\hline 4 & Gotong royong & 1 bulan sekali & Sekitar lingkungan \\
\hline 5 & Malam 1 Assuro & Hari ke 10 Muharram & Jalan sekitar danau \\
\hline 6 & $\begin{array}{l}\text { Upacara kelahiran } \\
\text { (Syukuran/selametan, } \\
\text { mitoni, brokohan, } \\
\text { sepasaran, selapanan) }\end{array}$ & $\begin{array}{l}\text { Awal kehamilan sampai usia bayi } \\
\text { 35 hari }\end{array}$ & $\begin{array}{l}\text { Rumah masyarakat } \\
\text { pemilik hajat }\end{array}$ \\
\hline 7 & $\begin{array}{l}\text { Upacara kematian (Ngesur } \\
\text { tanah/geblag, nelung dina, } \\
\text { mitung dina, matang puluh, } \\
\text { nyatus dan mendak) }\end{array}$ & $\begin{array}{l}\text { Hari 1-3, hari ke 7, hari ke 40, hari } \\
\text { ke 100, pengulangan hari ke 100 }\end{array}$ & Rumah duka pemilik hajat \\
\hline 8 & $\begin{array}{l}\text { Kenduren/kenduri } \\
\text { (wetonan, sabanan, likuran, } \\
\text { ba'kdan, muludan) }\end{array}$ & $\begin{array}{l}\text { Saat kelahiran, sebelum puasa } \\
\text { Ramadhan, 21 Ramadhan, 1 } \\
\text { Syawal atau Idul Fitri, 12 bulan } \\
\text { Maulud atau Maulid Nabi } \\
\text { Muhammad S.A.W. }\end{array}$ & Rumah, surau dan masjid \\
& & & \\
\hline
\end{tabular}

\section{Potensi Sumber Daya Ekowisata}

\section{a. Keindahan Lanskap}

Potensi sumber daya ekowisata di Danau Way Jepara tersusun dari perpaduan view yang saling mendukung dan membentuk lanskap. Lanskap tersebut memiliki potensi untuk dikembangkan menjadi daya tarik dan atraksi ekowisata, dikarenakan memiliki potensi keindahan alam. Potensi sumber daya ekowisata yang telah didokumentasikan dapat dilihat pada Gambar 3.

\section{View Lorong Jalan}

View lorong jalan di lokasi tersusun atas deretan pohon yang berumur puluhan tahun. View pohon yang mendominasi yaitu pohon Jati (Tectona grandis) dan Mahoni (Swietenia 
macrophylla).Tajuk pepohonan yang tinggi dengan perpaduan suasana alam yang indah dan menciptakan iklim mikro yang sejuk serta suasana nyaman. View tegakan pohon yang terdapat di kanan dan kiri jalan dapat dimanfaatkan menjadi atraksi ekowisata, atraksi yang dapat di kembangkan yaitu dengan penyediaan jalan setapak untuk jogging track dan jalur bersepeda. View tersebut dapat dilihat pada Gambar 3 (a).

\section{View Arboretum}

Terdapat 3 lokasi arboretum yang ada di Danau Way Jepara, di dalamnya terdapat 29 spesies pohon dari berbagai fase, yaitu: semai, tiang, pancang dan pohon, diameter batang pohon beragam, antara $1-90 \mathrm{~cm}$ dan memiliki tinggi mencapai $35 \mathrm{~m}$. Arboretum tersebut menjadi habitat tumbuhan dan satwa liar, sebagai pengatur tata air, filtrasi air yang masuk ke danau, cadangan karbon, penyedia oksigen dan pengatur iklim mikro.

Tajuk pohon yang rapat di arboretum berpadu dengan hijaunya rumput memberikan suasana sejuk dan santai, dapat membuat pikiran menjadi tenang dan menghilangkan rasa penat. Di bawah pepohonan di arboretum dapat digunakan sebagai camping ground. Selain itu kekayaan jenis spesies pohon.dapat dijadikan. sebagai wisata edukasi dan bahan penelitian. Di lokasi ini juga pengunjung dapat mengamati dan menikmati suara burung yang beraneka ragam secara langsung. Kondisi arboretum dapat dilihat pada Gambar 3 (b).

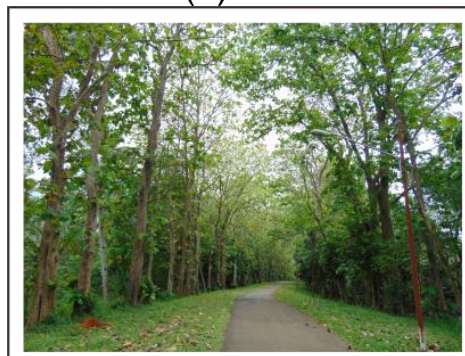

(a)

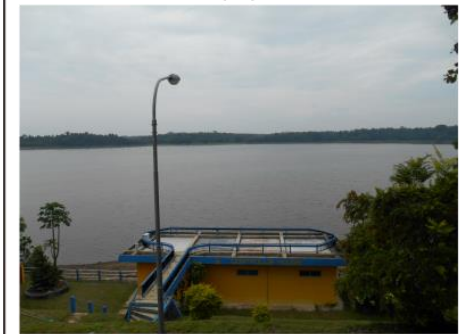

(d)

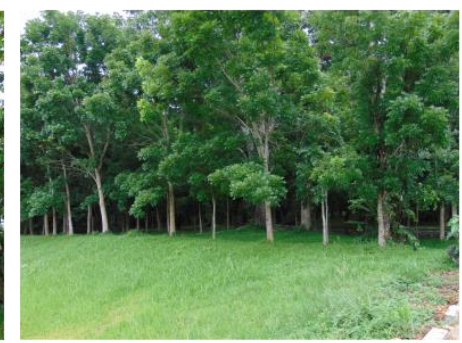

(b)

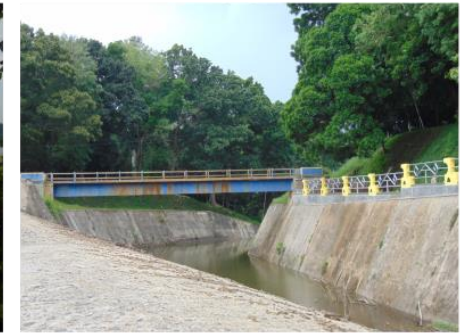

(e)

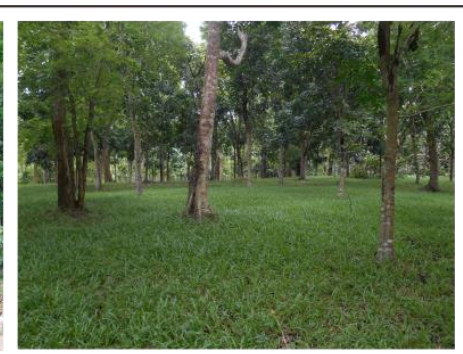

(c)

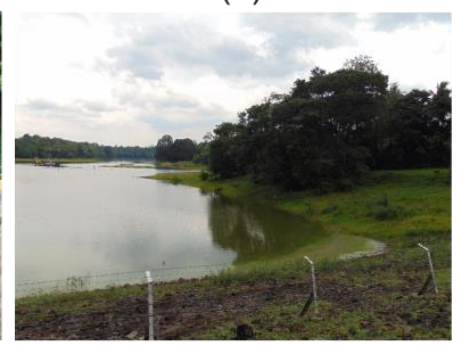

(f)

Keterangan: (a) view jalan, (b) view arboretum(c) view camping ground, (d) view danau, (e) view bendungan dan jembatan, serta (f) view green belt riparian fotrest.

Gambar 3. Potensi sumber daya ekowisata di Danau Way Jepara.

Figure 3. Potential ecotourism resources in the lake Way Jepara.

\section{View Danau}

View danau merupakan perpaduan jernihnya air dan hijaunya hutan riparian seperti pada Gambar 3 (f). Pengembangan yang dapat dilakukan yaitu pengembangan wahana permainan air (seperti perahu dayung, perahu kano, memancing, keramba budidaya ikan air tawar dan rumah makan apung). Danau Way Jepara memiliki kedalaman yang bervariasi, sehingga perlu dibuat pembagian zona aman untuk wahana permainan air dan diperlukan pengawasan yang intensif. View danau dapat dilihat pada Gambar 3 (d)

\section{View Bendungan}

Lokasi bendungan berdekatan dengan jembatan. Fungsi bendungan tersebut sebagai penampung air limpasan saat air danau meluap. View bendungan dan jembatan dapat dilihat pada Gambar 3 (e). Potensi yang dapat dimaksimalkan yaitu sebagai salah satu 
spot selvie. Bentuk pengelolaan yang dapat dilakukan yaitu dengan rehabilitasi dan pengecatan ulang supaya membangkitkan minat wisatawan untuk berfoto.

\section{b. Flora dan Fauna}

Flora dan fauna yang terdapat di Danau Way Jepara memiliki tingkat kekayaan yang relatif tinggi. Potensi flora dan fauna tersebut tersebar di sekitar jalan, arboretum dan green belt riparian forest. Keberadaan vegetasi yang ada di Danau Way Jepara secara umum bermanfaat sebagai habitat satwa liar, juga dapat dimanfaatkan sebagai daya tarik ekowisata karena memberikan keindahan, kesejukan, sebagai sarana edukasi dan penelitian

\section{Flora}

Kehadiran vegetasi pada suatu landscape akan memberikan dampak positif bagi keseimbangan ekosistem dalam skala yang lebih luas. Secara umum, peranan vegetasi dalam suatu ekosistem terkait dengan pengaturan keseimbangan karbon dioksida dan oksigen dalam udara, perbaikan sifat fisik, kimia dan biologis tanah, pengaturan tata air tanah dan lain-lain (Indriyanto, 2006). Menurut Marsono (1991), susunan vegetasi riparian mempunyai peranan penting bagi ekosistem perairan, sebagai pemasok nutrien dan energi ke dalam sistem perairan. Banyak ikan-ikan yang sumber pakannya bergantung dari luar perairan. Di samping itu, vegetasi riparian juga berperan untuk menahan erosi, pengendalian masuknya nutrien dan bahan-bahan toksik yang masuk ke perairan serta menyimpan air tanah. Riparian bermanfaat bagi ekosistem setempat dan daerah ini juga dimanfaatkan sebagai daerah wisata yang dapat menjadi pendapatan masyarakat setempat Spesies pohon yang terdapat di Danau Way Jepara ditampilkan seperti pada Tabel 2.

Tabel 2. Keanekaragaman flora di Danau Way Jepara.

Table 2. The flora diversity in the Lake Way Jepara.

\begin{tabular}{lll}
\hline No. & \multicolumn{1}{c}{ Spesies } & \multicolumn{1}{c}{ Nama Ilmiah } \\
\hline 1 & $\begin{array}{l}\text { Mahoni daun } \\
\text { besar }\end{array}$ & (Swietenia macrophylla) \\
\hline 2 & Mahoni daun kecil & (Swietenia mahagoni) \\
\hline 3 & Bungur lilin & (Lagestromia speciosa) \\
\hline 4 & Flamboyan & (Delonix regia) \\
\hline 5 & Sonokeling & (Delbergia lantifolia) \\
\hline 6 & Akasia & (Acacia auricuriformis) \\
\hline 8 & Bayur & (Pterospermum \\
\hline 9 & Mangga & javanicum) \\
\hline 10 & Jengkol & (Mangivera indica) \\
& & (Arescentia cuyette) \\
\hline 11 & Kerai payung & (Felicium decipiens) \\
\hline 12 & Aren & (Arenga pinata) \\
\hline 13 & Bendo & (Artocarpus elasticus) \\
\hline
\end{tabular}

\begin{tabular}{lll}
\hline 14 & Rengas & (Gluta rengas) \\
\hline 15 & Jati & (Tectona grandis) \\
\hline 16 & Waru & (Hibiscus tiliaceus) \\
\hline 17 & Tangkil & (Gnetum gnemon) \\
\hline 18 & Sengon & (Albizia chinensis) \\
\hline 19 & Beringin & (Ficus benjamina) \\
\hline 20 & Merbau darat & (Insia bijuga) \\
\hline 22 & Kihujan & (Samanea saman) \\
\hline 23 & Netai & (Parkia speciosa) \\
\hline 25 & Mindi & (Artocarpus heterophyllus) \\
\hline 26 & Wareng & (Melia azedarach) \\
\hline 27 & Salam & (Pinus merkusii) \\
\hline 28 & Laban & (Gemelina arborea) \\
\hline 29 & Matoa/ Sapen & (Syzygium polyanthum) \\
\hline & & (Pometia pinnata) \\
\hline
\end{tabular}

Spesies pohon yang telah teridentifikasi sebanyak 29 spesies pohon, sedangkan masih ada beberapa spesies pohon yang belum diketahui. Sebagian spesies pohon yang terdapat di Danau Way Jepara adalah merupakan pohon introduksi yang ditanam sekitar tahun 1972. Manfaat secara umum yang dihasilkan di antaranya sebagai bahan bangunan, kayu bakar, penghasil buah, peneduh, estetika dan juga beberapa tanaman dapat diolah menjadi obat tradisional.

Pohon yang terdapat di lokasi arboretum dapat dimanfaatkan sebagai atraksi permainan outbond dan rumah pohon. Beberapa tempat wisata di daerah lain juga telah memanfaatkan potensi pohon sebagai rumah pohon, salah satu tempat tersebut yaitu: Omah Kayu Paralayang di Malang, Magical Treehouse di Pantai Balangan Bali dan tempat serupa lainnya. Pengembangan lain berupa jembatan gantung (canopy trail) seperti di PPKAB Bodogol. Pengembangan 
tersebut dinilai lebih natural dan menghindari dibangunnya fasilitas permanen, mengingat Danau Way Jepara adalah catchment area yang harus dipertahankan.

Potensi kekayaan jenis pohon dapat mendukung wisata edukasi. berdasarkan prinsip pengembangan ekowisata peraturan Menteri Dalam Negeri No. 33 Tahun 2009, yang di dalamnya menyebutkan prinsip edukasi, yaitu: mengandung unsur pendidikan untuk mengubah persepsi seseorang agar memiliki kepedulian, tanggung jawab dan komitmen terhadap pelestarian lingkungan dan budaya. Alternatif pengembangan antara lain dengan pengadaan papan nama pohon, pusat informasi dan mengintroduksi koleksi pohon langka dari berbagai tempat. Sehingga pengunjung dapat belajar berbagai spesies pohon di Danau Way Jepara. Pengembangan serupa telah dilakukan di Kebun Raya Bogor, Kebun Raya Cibodas, Taman Hutan Persahabatan Manggala Wanabakti dan beberapa tempat lainnya.

\section{Fauna}

Berdasarkan survei yang dilakukan kondisi lingkungan terlihat belum mengalami pencemaran, kekayaan spesies fauna relatif tinggi. Fauna yang telah teridentifikasi sebanyak 26 spesies. Berdasarkan penjelasan informan kunci terdapat beberapa satwa yang sudah jarang dijumpai seperti lutung, siamang, surili, babi hutan dan lutung budeng. Sedangkan untuk populasi kera ekor panjang sangat melimpah dan dianggap sebagai hama bagi masyarakat karena merusak tanaman di kebun masyarakat. Kelangkaan fauna akibat perburuan liar yang dilakukan oleh masyarakat sekitar selain itu sangsi yang diberikan hanya sebatas teguran dan belum ada sangsi hukum yang diterapkan. Keanekaragaman fauna dapat dilihat pada Tabel 3.

Tabel 3. Survei keanekaragaman fauna di daratan.

Table 3. Survei of animals diversity in the mainland.

\begin{tabular}{|c|c|c|c|c|}
\hline No & Spesies & Nama ilmiah & Manfaat & $\begin{array}{c}\text { Status } \\
\text { Perlindungan }\end{array}$ \\
\hline 1 & $\begin{array}{l}\text { Kera ekor } \\
\text { panjang }\end{array}$ & $\begin{array}{l}\text { (Macaca } \\
\text { fascicularis) }\end{array}$ & Penyebar benih & Dilindungi \\
\hline 2 & Lutung & (Trachypithecus) & Penyebar benih & Dilindungi \\
\hline 3 & Siamang & $\begin{array}{l}\text { (Simphalangus } \\
\text { syndactylus) }\end{array}$ & Penyebar benih & Dilindungi \\
\hline 4 & Beruk & $\begin{array}{l}\text { (Macaca } \\
\text { nemestrina) }\end{array}$ & Penyebar benih & Dilindungi \\
\hline 5 & Macan akar & (Felix bengalensis) & Predator alami & Dilindungi \\
\hline 6 & Ayam hutan & (Gallus galus) & $\begin{array}{l}\text { Konsumen dan } \\
\text { pengendali rantai } \\
\text { makanan }\end{array}$ & Tidak dilindungi \\
\hline 7 & Belibis & (Dendrocygninae) & Pengendali ekosistem & Dilindungi \\
\hline 8 & Kukang & $\begin{array}{l}\text { (Nycticebus } \\
\text { coucang) }\end{array}$ & Penyebar benih & Dilindungi \\
\hline 9 & Tupai & (Scandentia sp.) & Penyebar benih & Tidak dilindungi \\
\hline 10 & Bajing tanah & (Lariscus hoseii) & Penyebar benih & Tidak dilindungi \\
\hline 11 & Biawak & (Veranus salvator) & $\begin{array}{l}\text { Sebagai obat penyakit } \\
\text { kulit }\end{array}$ & Tidak dilindungi \\
\hline 12 & $\begin{array}{l}\text { Cekakak } \\
\text { sungai }\end{array}$ & $\begin{array}{l}\text { (Todiramphus } \\
\text { chloris) }\end{array}$ & $\begin{array}{l}\text { Daya tarik bird } \\
\text { watching }\end{array}$ & Tidak dilindungi \\
\hline
\end{tabular}




\begin{tabular}{|c|c|c|c|c|}
\hline 13 & Kutilang & $\begin{array}{l}\text { (Pycnonotus } \\
\text { aurigaster) }\end{array}$ & $\begin{array}{l}\text { Penyebar benih dan } \\
\text { daya tarik bird } \\
\text { watching }\end{array}$ & Tidak dilindungi \\
\hline 14 & Raja udang & (alcedinidae Sp.) & $\begin{array}{l}\text { Daya tarik bird } \\
\text { watching }\end{array}$ & Tidak dilindungi \\
\hline 15 & Murai & $\begin{array}{l}\text { (Copsychus } \\
\text { malabaricus) }\end{array}$ & $\begin{array}{l}\text { Daya tarik bird } \\
\text { watching }\end{array}$ & Dilindungi \\
\hline 16 & Kuntul & (ardiedae Sp.) & $\begin{array}{l}\text { Daya tarik bird } \\
\text { watching }\end{array}$ & Dilindungi \\
\hline 17 & Pipit & (Estrildidae) & $\begin{array}{l}\text { Daya tarik bird } \\
\text { watching }\end{array}$ & Tidak dilindungi \\
\hline 18 & Elang hitam & $\begin{array}{l}\text { (Ictinaetusmalainen } \\
\text { sis) }\end{array}$ & $\begin{array}{l}\text { Daya tarik bird } \\
\text { watching }\end{array}$ & Dilindungi \\
\hline 19 & $\begin{array}{l}\text { Cininen } \\
\text { kelabu }\end{array}$ & $\begin{array}{l}\text { (Orthotomus } \\
\text { ruriceps) }\end{array}$ & $\begin{array}{l}\text { Daya tarik bird } \\
\text { watching }\end{array}$ & Tidak dilindungi \\
\hline 20 & Kepodang & (Oriolus chinensis) & $\begin{array}{l}\text { Daya tarik bird } \\
\text { watching }\end{array}$ & Dilindungi \\
\hline 21 & Burung hantu & (strigiformes Sp.) & $\begin{array}{l}\text { Daya tarik bird } \\
\text { watching }\end{array}$ & Tidak dilindungi \\
\hline 22 & Pecuk ular & (Anhinga anhinga) & $\begin{array}{l}\text { Daya tarik bird } \\
\text { watching }\end{array}$ & Dilindungi \\
\hline 23 & Kuntul kerbau & (Bubulcus ibis) & $\begin{array}{l}\text { Daya tarik bird } \\
\text { watching }\end{array}$ & Dilindungi \\
\hline 24 & $\begin{array}{l}\text { Ular sanca } \\
\text { kembang }\end{array}$ & (Phyton reticulatus) & Predator alami & Dilindungi \\
\hline 25 & $\begin{array}{l}\text { Ular king } \\
\text { kobra }\end{array}$ & $\begin{array}{l}\text { (Ophiophagus } \\
\text { hannah) }\end{array}$ & Predator alami & Tidak dilindungi \\
\hline 26 & Ular welang & $\begin{array}{l}\text { (Bungarus } \\
\text { candidus) }\end{array}$ & Predator alami & Tidak dilindungi \\
\hline
\end{tabular}

Berdasarkan data survei keanekaragaman fauna, maka dapat dianalisis bahwa kekayaan jenis satwa merupakan jenis mamalia sebanyak 8 jenis, 14 jenis burung dan 4 jenis reptil. Manfaat yang diketahui di antaranya yaitu sebagai penyebar benih, pengendali ekosistem, menjaga rantai makanan, dan sebaga daya tarik bird watching.

Kekayaan jenis spesies ikan air tawar yang telah teridentifikasi sebanyak 21 spesies. Kondisi air yang jernih dan belum mengalami pencemaran lingkungan membuat spesies ikan tersebut dapat berkembang biak dengan baik. Dalam menunjang atraksi ekowisata, potensi tersebut dapat dikembangkan untuk wisata kuliner dan makanan khas, budidaya ikan keramba, penyediaan tempat kuliner serta masakan lokal berbahan dasar ikan air tawar. Atraksi lain yang dapat dilakukan yaitu memancing ikan di keramba atau di danau. Kekayaan jenis spesies ikan dapat dilihat pada Tabel 4.

Tabel 4. Kekayaan jenis spesies ikan.

Table 4. The richness of species of fish.

\begin{tabular}{cll}
\hline No & Spesies & \multicolumn{1}{c}{ Nama ilmiah } \\
\hline 1 & Nila & (Oreochromis niloticus) \\
\hline 2 & Patin & (pangasius Sp.) \\
\hline 3 & Gabus & (Channa striata) \\
\hline 4 & Betutu & (Oxyeleotris marmorata) \\
\hline 5 & Mujair & $\begin{array}{l}\text { (Oreochromis } \\
\text { mossambicus) }\end{array}$ \\
\hline
\end{tabular}

\begin{tabular}{lll}
\hline 6 & Melem & (Osteochilus vittatus) \\
\hline 7 & Oskar & (Astronotus ocellatus) \\
\hline 8 & Tawes & $\begin{array}{l}\text { (Barbonymus } \\
\text { gonionotus) }\end{array}$ \\
\hline 9 & $\begin{array}{l}\text { Sapu- } \\
\text { sapu }\end{array}$ & $\begin{array}{l}\text { (Hypostomus } \\
\text { plecostomus) }\end{array}$ \\
\hline 10 & Belut & (Monopterus albus) \\
\hline 11 & Baung & (Hemibagrus nemurus) \\
\hline
\end{tabular}




\begin{tabular}{lll}
\hline 12 & Lele & (clarias Sp.) \\
\hline 13 & $\begin{array}{l}\text { Lunjar } \\
\text { padi }\end{array}$ & (Rasbora argirotaenia) \\
\hline 14 & $\begin{array}{l}\text { Sepat } \\
\text { siam }\end{array}$ & $\begin{array}{l}\text { (Trichogaster } \\
\text { trichopterus) }\end{array}$ \\
\hline 15 & Soleng/sili & $\begin{array}{l}\text { (macrognathus } \\
\text { aculeautus) }\end{array}$ \\
\hline 16 & Wader & (Rasbora jacosoni) \\
\hline 17 & Mas & (Cyprinus carpio) \\
\hline
\end{tabular}

\begin{tabular}{lll}
\hline 18 & Betok & (Anabas testudineus) \\
\hline 19 & Palung & $\begin{array}{l}\text { (Hampala } \\
\text { macrolepidota) }\end{array}$ \\
\hline 20 & Seren & (Anematichthys apogon) \\
\hline 21 & Udang & $\begin{array}{l}\text { Macrobrachium } \\
\text { rosenbergii }\end{array}$ \\
\hline
\end{tabular}

\section{c. Infrastruktur}

Jalan utama menuju Danau Way Jepara sudah menggunakan aspal dan tergolong cukup baik, namun di beberapa bagian masih terdapat kerusakan ringan. Kerusakan tersebut memerlukan perbaikan supaya memudahkan mobilitas dan meningkatkan aksesibilitas menuju titik atraksi di dalam lokasi wisata. Selain jalan utama juga terdapat jalan alternatif dari arah Register 38 Gunung Balak kondisinya masih kurang baik karena merupakan jalan batu onderlah dan hanya bisa dilalui dengan menggunakan sepeda motor, sehingga bagi wisatawan yang ingin menggunakan mobil diharapkan dapat menggunakan jalan utama.

Selain jalan utama dan jalan alternatif, di lokasi ekowisata juga tersedia infrastruktur jalan setapak, kondisi jalan setapak ini tergolong cukup baik dan dapat dilalui dengan berjalan santai. Bagi wisatawan yang ingin melakukan eksplorasi mengelilingi danau tersedia jalan tracking melingkar danau, jalan tracking ini kondisinya kurang baik, oleh sebab itu sangat diperlukan pembangunan dan perawatan jalur. Infrastruktur lainnya yaitu: jembatan, lahan parkir kendaraan, saluran irigasi dan sudah tersedia jaringan listrik serta jaringan komunikasi. Kondisi infrastruktur dapat dilihat seperti Gambar 5.

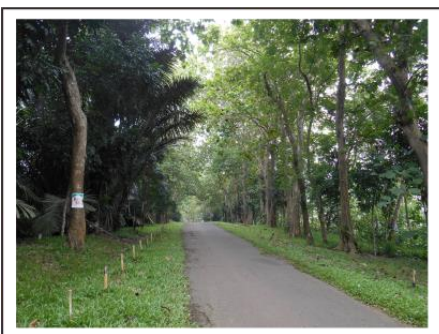

(a)

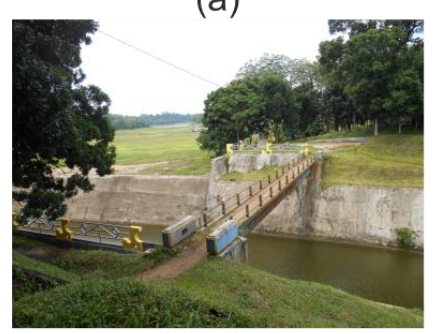

(d)

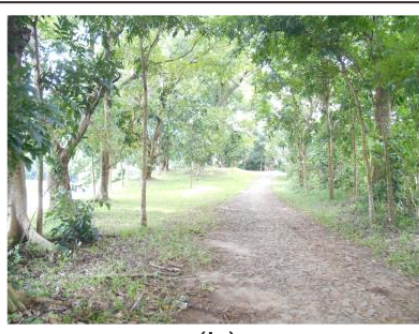

(b)

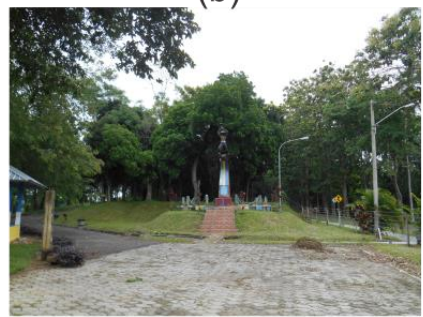

(e)

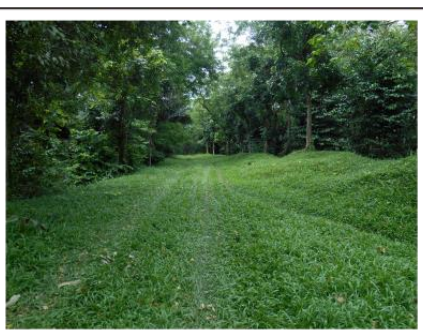

(c)

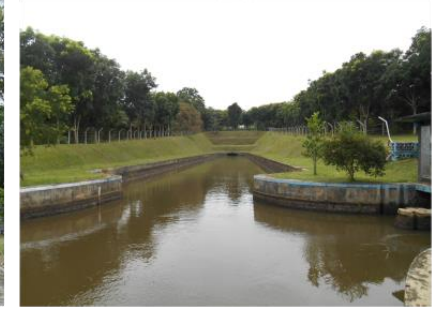

(f)

Keterangan: (a) jalan utama, (b) jalan alternatif, (c) jalan tracking, (d) jembatan, (e) lahan parkir dan (f) saluran irigasi.

Gambar 5. Infrastruktur yang tersedia di Danau Way Jepara. Figure 5. Infrastructure available in Lake Way Jepara. 


\section{d. Akomodasi}

Akomodasi yang tersedia yaitu: hotel (berjarak $5 \mathrm{~km}$ dari lokasi), camping ground (berlokasi di arboretum), vila dan home stay yang ada di sekitar rumah masyarakat. Kondisi hotel tergolong baik dengan pelayanan yang diberikan juga baik, kondisi vila operasional yang ada di lokasi kondisinya kurang terawat dan tidak dapat dijadikan untuk menginap. Lokasi camping ground dapat menampung hingga 30 tenda. Pengembangan yang dapat dilakukan yaitu: dengan rehabilitasi kondisi fisik dan pengadaan penyewaan peralatan hiking dan peningkatan fasilitas pelayanan di lokasi. Akomodasi dapat dilihat pada Gambar 5.

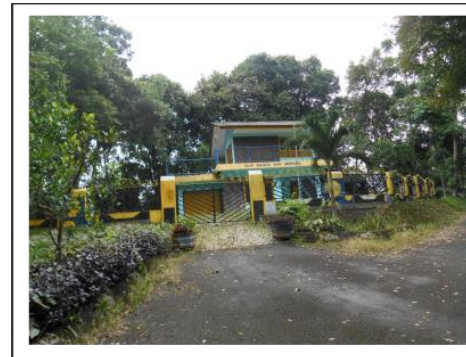

(a)

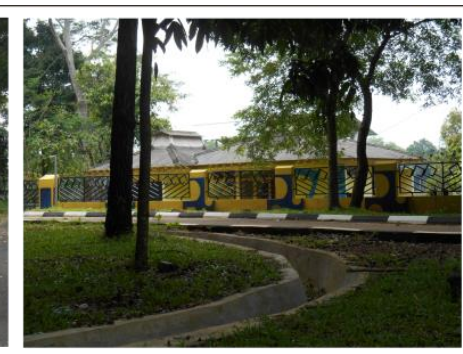

(b)

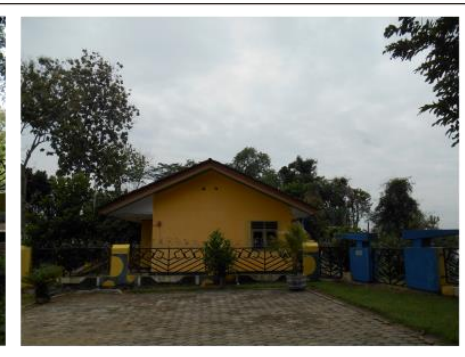

(c)

Keterangan: (a) vila, (b) mes dan (c) home stay.

Gambar 5. Akomodasi yang tersedia di Danau Way Jepara.

Figure 5. Accommodation available in Lake Way Jepara.

\section{e. Fasilitas dan Pelayanan}

Supaya kegiatan ekowisata berjalan lancar maka harus tersedia fasilitas dan pelayanan yang memadai. Fasilitas yang terdapat di lokasi kondisinya cukup baik, namun pelayanannya kurang memadai, kondisi fasilitas dan pelayanan tersebut dapat dilihat pada Gambar 6.

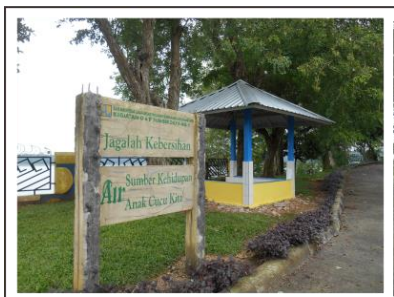

(a)

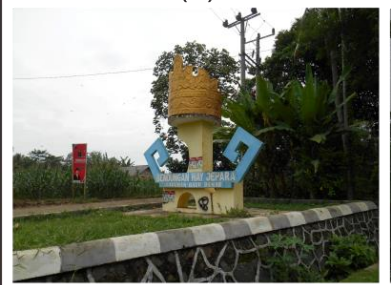

(d)

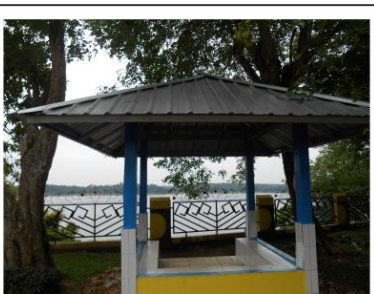

(b)

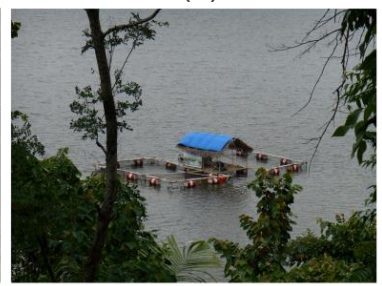

(e)

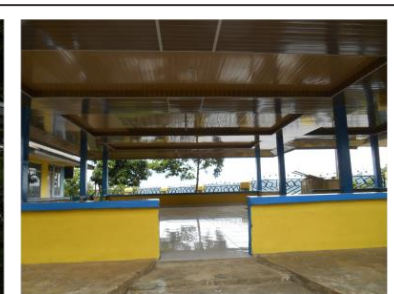

(c)

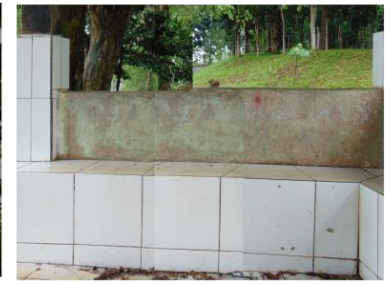

(f)

Keterangan: (a) papan himbauan, (b) gazebo, (c) aula terbuka, (d) ) tugu simbolis, (f) keramba dan (f) tempat duduk.

Gambar 6. Fasilitas ekowisata di Danau Way Jepara. Figure 6. Ecotourism facility in the Lake Way Jepara. 
Fasilitas dan pelayanan ekowisata di Danau Way Jepara dapat pendukung kegiatan ekowisata. Fasilitas dan pelayanan tersebut perlu di tingkatkan, supaya memberikan kepuasan bagi wisatawan. Berdasarkan penelitian Wiradipoetra dan Brahmanto, (2016) di Destinasi Wisata Ciwangun Indah Camp, menunjukkan bahwa penurunan kualitas daya tarik berpengaruh signifikan terhadap turunnya minat berkunjung wisatawan. Faktor kerusakan fasilitas akibat kurangnya perawatan dinilai sebagai pemicu persepsi negatif wisatawan terhadap daya tarik wisata, sehingga berdampak pada kurangnya minat untuk berkunjung. Menurut Siregar, (2017) tersedianya fasilitas di suatu obyek wisata merupakan kesiapan suatu sarana untuk dapat dioperasikan dan dapat memberikan kenyamanan pada wisatawan.

Intensitas kunjungan ke Danau Way Jepara saat ini mengalami penurunan. Penurunan aktivitas kunjungan diduga karena faktor keamanan, kelembagaan dan kondisi fasilitas serta pelayanan yang kurang memadai, hal tersebut membuat wisatawan merasa ragu untuk berkunjung.

\section{f. Persebaran Potensi Sumber Daya Ekowisata}

Danau Way Jepara mempunyai potensi yang besar dan belum dimanfaatkan dengan baik. Menurut Masyono dan Suhada (2015), tantangan pengembangan wisata tidak mudah dan karena itu diperlukan upaya maksimal dari Pemerintah Daerah Kabupaten Lampung Timur serta berbagai pihak terutama instansi/lembaga dan dunia usaha yang secara langsung maupun tidak langsung menunjang pembangunan kepariwisataan, untuk saling bersinergi.

Berdasarkan peta persebaran potensi sumber daya ekowisata di Danau Way Jepara, dapat dianalisis bahwasanya lokasi potensi yang dapat dikembangkan sebagai item daya tarik dan atraksi ekowisata terbagi menjadi dua zona, yaitu: Zona A yang terletak di hulu dan Zona B yang terletak di hilir, kedua zona dihubungkan oleh koridor jalan utama. Pengembangan ekowisata dapat dipusatkan pada sumber daya ekowisata unggulan. Dengan pembangunan fasilitas dan pelayanan yang dilengkapi sarana pendukung maka pengelolaan lokasi ekowisata akan lebih baik dan dari segi ekonomi akan menyerap lebih banyak tenaga kerja lokal. Potensi sumber daya ekowisata tersebar seperti pada Gambar 9. 


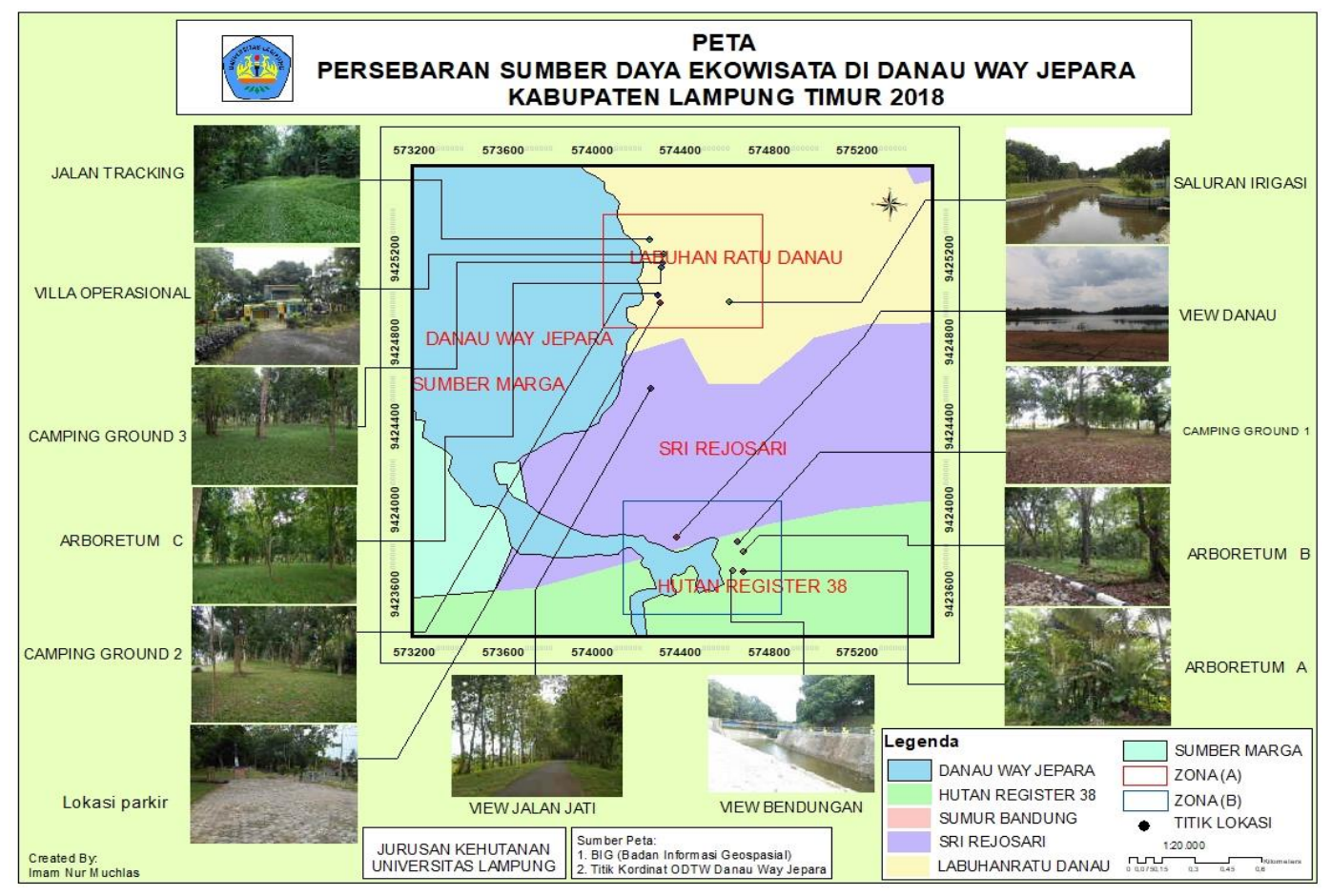

Gambar 9. Peta persebaran sumber daya ekowisata di Danau Way Jepara. Figure 9. The Map distribution of ecotourism resource in the Lake Way Jepara

\section{Kesimpulan}

Potensi sumber daya ekowisata yang terdapat di daratan dan di perairan danau meliputi: potensi lanskap, flora dan fauna, fasilitas dan pelayanan, akomodasi dan infrastruktur. Lanskap daratan meliputi view lorong jalan, view arboretum, view bendungan dan keindahan lanskap perairan danau. Sumber daya flora dan fauna meliputi 29 spesies pohon, 26 spesies satwa dan 21 spesies ikan. Infrastruktur yang tersedia meliputi jalan utama, jalan alternatif, jalan tracking, jembatan, parkir dan saluran irigasi. Fasilitas dan pelayanan yang tersedia meliputi: papan himbauan, gazebo, tugu simbolis, aula terbuka dan tempat duduk. Akomodasi yang tersedia yaitu: hotel, camping ground, vila operasional serta home stay. Persebaran sumber daya ekowisata mengelompok dalam dua zona, sehingga akan memudahkan dalam perencanaan dan pengembangan ekowisata.

\section{Daftar Pustaka}

BPS Kabupaten Lampung Timur. 2017. Way Jepara Dalam Angka 2017. Buku. BPS Kabupaten Lampung Timur. p. 146.

Dinas Pekerjaan Umum Kabupaten Lampung Timur. 2016. Buku Inventarisasi O\&P KPD PU Way Jepara. pp 3-7. 
Hijriati, E. \& Mardiana, R. 2014. Pengaruh ekowisata berbasis masyarakat terhadap perubahan kondisi ekologi, sosial dan ekonomi di Kampung Batusuhunan Sukabumi. Journal Sosiologi Pedesaan, 2(3), 146-159.

Hilman, Y. A. 2017. Kelembagaan kebijakan pariwisata dilevel desa. Journal IImu Pemerintahan, Universitas Muhammadiyah Ponorogo, 2(2), 150-163.

Indriyanto. 2006. Ekologi Hutan. Buku. Jakarta: Penerbit Bumi Aksara.

Masyono, S.A. \& Suhada, B. 2015. Strategi pengembangan sektor kepariwisataan di Kabupaten Lampung Timur. Journal Derivatif, 9(1), 11.

Menteri Dalam Negeri. 2009. Peraturan Menteri Dalam Negeri No. 33 Tahun 2009 Tentang Pedoman Pengembangan Ekowisata di Daerah.

Priyono, Y. 2012. Pengembangan kawasan ekowisata Bukit Tangkiling berbasis masyarakat. Journal Perspektif Arsitektur, 7(1), 17.

Siregar, Y.C. 2017. Fasilitas pada ekowisata Danau Naga Sakti di Kabupaten Siak Sri Indrapura Riau. Journal Online Mahasiswa FISIP, 4(2), 11.

Winasis A. 2016. Efektivitas program pengembangan desa wisata melalui kelembagaan dalam peningkatan sumber daya alam (SDA). Journal Ilmu Sos dan IImu Politik JISIP, 5(2), 12-16.

Wiradipoetra, F.A. \& Brahmanto, E. 2016. Analisis persepsi wisatawan mengenai penurunan kualitas daya tarik wisata terhadap minat berkunjung. Journal Pariwisata, 3(2), 9. 